\title{
Springing into life: the harmony of human anatomy, nature, and patient care
}

\author{
Julia H. Miao, Kathleen H. Miao \\ Cornell University, New York, NY, USA \\ Correspondence to: Julia H. Miao. Cornell University, New York, NY, USA. Email: jhm344@cornell.edu.
}

Submitted Mar 08, 2020. Accepted for publication Apr 02, 2020.

doi: $10.21037 /$ cdt.2020.04.03

View this article at: http://dx.doi.org/10.21037/cdt.2020.04.03

Dedicated to resilient patients from all around the globe, "Springing into Life" is a collaborative collection of mixed media and 3D digital poly art, portraying the harmony between nature and humanity and the celebration of community, healing, and regrowth amidst a dynamic world of chaos.

Bridging the arts and sciences of medicine, each artwork portrays a unique anatomical organ immersed in vast lands of lush greenery or flowers. They not only represent the vibrant colors of life but also symbolize the beauty of the human body and the unique narrative voices of our diverse patient communities.

In "Soulful Eyes", adventurous tree branches, enveloped in red and gold leaves, emerge from the eye like the complex vessels and innervation that supply our vision (Figure 1). They portray the unique intricacy of the human eye's anatomy. Simultaneously, a bed of blooming flowers encircles the organ, representing a metaphorical birth of spring and new beginnings. By superimposing spring flowers together with fall leaves, the artwork creates a blurred dichotomy of the two seasons-the young and the old-emblematic of the valuable connection of shared illness experiences that unite both our young and old patient communities. Propelled into the thrusts of each passing season and springing into full bloom, "Soulful Eyes" thus creates a thoughtful lens on the values of life, birth, and connection, both in nature and in humanity.

"The Touching Tree" draws inspiration from the various happenings on our skin, symbolizing the stage of life of growth and reflection (Figure 2). In face of the ups and downs of life, the skin and the tree grow through the experiences of a lifelong journey. To withstand

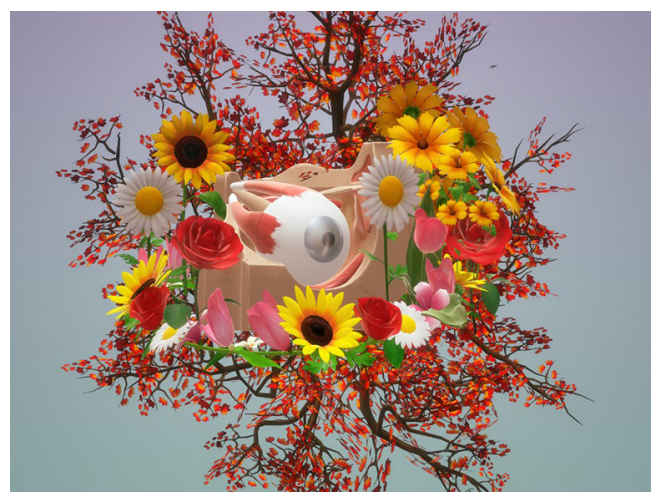

Figure 1 Soulful Eyes.

unpredictable weather like supple trees, our skin cells adapt, regenerate, and become resilient through experience. The colorful visual architecture purposefully depicts the bending trees sprouting from the skin, further illuminating humanity and nature emerging as one, as well as demonstrating adaptability in face of new challenges. Lastly, like the roots of trees, the blood vessels that supply the skin provide essential nutrients for healing and growth.

In "Heartfelt Hope", flowers emerge from the soul of the heart, paralleling imagery of a bouquet of flowers, blooming next to patients' bedsides as their hearts beat through the stages of life (Figure 3). With each beat, the heart's blood flow pumps life throughout the body just as each seed brings forth a flourishing flower. For patients, the heart and flowers symbolize hope, love, and empathy, continuing to highlight the beauty of healing through the synergy of man and nature from the beginning to the end.

Collectively, the three works of art illuminate the 


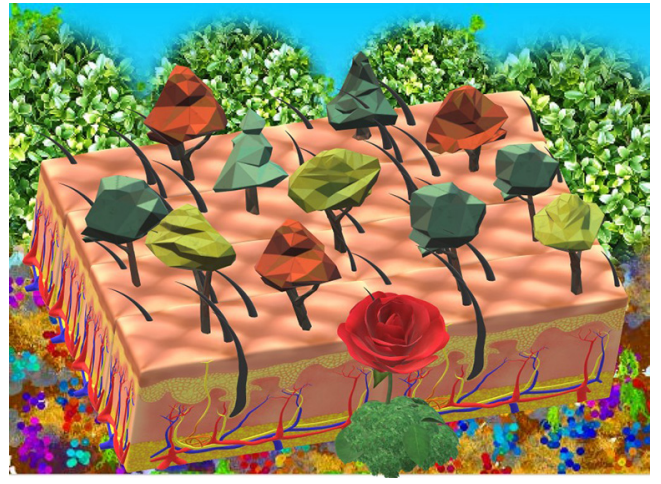

Figure 2 The Touching Tree.

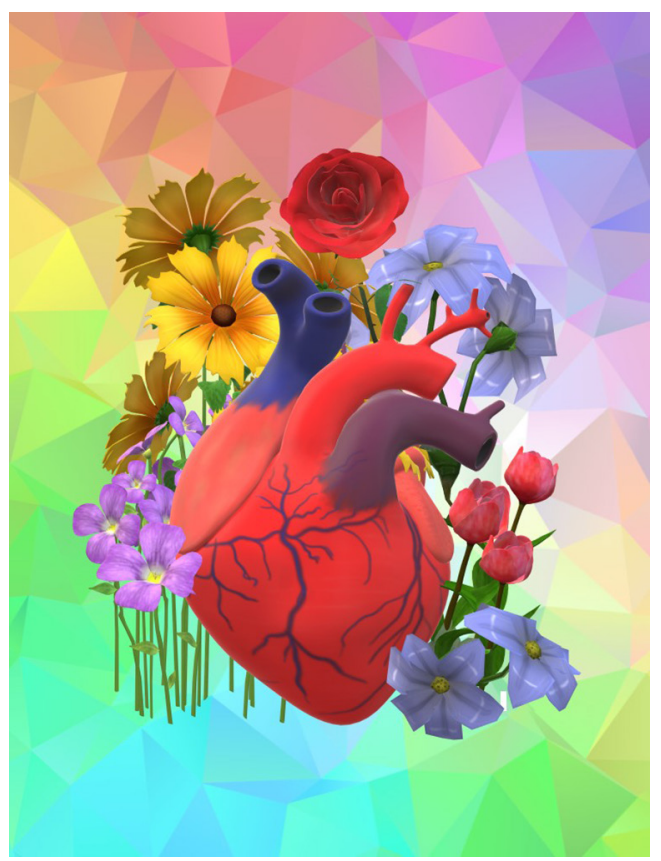

Figure 3 Heartfelt Hope.

metaphorical narrative on the journey of life, encouraging discussion and a new appreciation for the anatomy of the human body and the serenity of healing with body, soul, and mind. The beauty of our mother Earth, integrated together with 3D digital art of the organs of life, thus creates an enhanced humanistic and scientific quality and ultimately highlights the harmony between nature and humanity.

\section{Author's statement}

Julia H. Miao and Kathleen H. Miao graduated from Cornell University with BAs in Biological Sciences. Dedicated to caring for their patient communities, Julia and Kathleen enjoy engaging in their passions for humanistic medicine through patient advocacy, research, and visual art narratives. Their photography and artworks have been featured and displayed in galleries and exhibits across the country. Both authors contributed equally to the artworks and writing of the article.

\section{Acknowledgments}

Funding: None.

\section{Footnote}

Conflicts of Interest: All authors have completed the ICMJE uniform disclosure form (available at http://dx.doi. org/10.21037/cdt.2020.04.03). The authors have no conflicts of interest to declare.

Ethical Statement: The authors are accountable for all aspects of the work in ensuring that questions related to the accuracy or integrity of any part of the work are appropriately investigated and resolved.

Open Access Statement: This is an Open Access article distributed in accordance with the Creative Commons Attribution-NonCommercial-NoDerivs 4.0 International License (CC BY-NC-ND 4.0), which permits the noncommercial replication and distribution of the article with the strict proviso that no changes or edits are made and the original work is properly cited (including links to both the formal publication through the relevant DOI and the license). See: https://creativecommons.org/licenses/by-nc-nd/4.0/.
Cite this article as: Miao JH, Miao KH. Springing into life: the harmony of human anatomy, nature, and patient care. Cardiovasc Diagn Ther 2021;11(1):339-340. doi: 10.21037/ cdt.2020.04.03 